S. Afr. J. Agric. Ext.

Vol. 47 No. 1, 2019: 164 - 178

http://dx.doi.org/10.17159/2413-3221/2019/v47n1a497
Musara, Musemwa,

Mushunje, Mutenje \& Pfukwa

(License: CC BY 4.0)

\title{
SORGHUM VALUE CHAIN ANALYSIS IN SEMI-ARID ZIMBABWE
}

Musara, J.P., ${ }^{1,2}$ Musemwa, L., ${ }^{3}$ Mushunje, A., ${ }^{4}$ Mutenje, M. ${ }^{5}$ and Pfukwa, C. 6

Correspondence Author: J.P. Musara, Email: jpmusara@gmail.com

\section{ABSTRACT}

The role of extension in strengthening relationships among stakeholders along agricultural commodity value chains remains an important discussion point especially with orphan crops in semi-arid areas. The study used a participatory framework to analyse the sorghum value chain in the Mid Zambezi Valley of Zimbabwe. A sample comprising of 380 small scale farmers, proportionately selected from five major sorghum producing wards, was used. Six agrodealers, 15 traders, 10 retailers, three wholesalers, and two processors were also sampled. In addition, focus group discussions, informant interviews, questionnaires and reviews of financial records were conducted. Input supply systems for sorghum are weakly developed and production is stalled by inappropriate innovations including seed and fertilizer application. Marketing and processing channels are limited due to erratic supply and low producer prices. Demand for sorghum inputs can be created by engaging extension agents in helping farmers with realising the benefits of using improved sorghum seed varieties and fertilizer in sorghum production. This will smoothen the flow of sorghum products along strategic value chain nodes.

Keywords: Sorghum, small scale farmers, value chain, extension networks, marketing margins, agribusiness

\section{INTRODUCTION}

\subsection{Background}

Efficient agricultural value chains are important in generating and sustaining wealth (Gulati et al., 2007; Pye-Smith, 2013; Sarris \& Morrison, 2010). Asymmetry exists in most value chains with farmers extracting the least share. Small scale farmers depend on farming for livelihoods and augment this with different forms of off-farm income. Sorghum remains important for sustainability of small scale farmers' subsistence, social and economic livelihoods in semi-arid and arid communities of Southern Africa. Migrating towards market driven sorghum production can catalyse effective participation in the value chain and improve welfare through efficient utilisation of the limited resources and beneficial networking. However, sorghum

\footnotetext{
${ }^{1}$ Faculty of Agriculture and Environmental Sciences, Bindura University of Science Education, P. Bag 1020, Bindura, Zimbabwe. E-mail: jpmusara@gmail.com

2 Faculty of Agricultural Sciences, Women's University in Africa, P.O. Box GD 32, Greendale, Harare, Zimbabwe. Tel: +263-775546202. E-mail: jpmusara@gmail.com

${ }^{3}$ Faculty of Agriculture and Environmental Sciences, Bindura University of Science Education, P. Bag 1020, Bindura, Zimbabwe. E-mail: 1musemwa@gmail.com

${ }^{4}$ Department of Agricultural Economics, University of Fort Hare, P. Bag X1314, Alice 5700, Republic of South Africa. E-mail: amushunje@ufh.ac.za

${ }^{5}$ CIMMYT, Southern Africa Regional Office, P.O Box MP 154, Mount Pleasant, Harare, Zimbabwe. E-mail: m.mutenje@cgiar.org

65 Professor and Faculty Dean. Faculty of Social Sciences and Humanities, Bindura University of Science Education, P. Bag 1020, Bindura, Zimbabwe. E-mail: c4pfukwa@gmail.com
} 
S. Afr. J. Agric. Ext.

Vol. 47 No. 1, 2019: 164 - 178

http://dx.doi.org/10.17159/2413-3221/2019/v47n1a497
Musara, Musemwa,

Mushunje, Mutenje \& Pfukwa

(License: CC BY 4.0)

based livelihood strategies are compromised by multiple household specific and market related drawbacks (Mukarumbwa \& Mushunje, 2010). There is a double thronged challenge where small scale farmers attain low yields and are exposed to extremely unfavourable market relations thereby reducing net marketing margins. These farmers do not actively participate in rewarding value chain nodes. They face low market prices and high transaction costs. This is due to remoteness of prime production zones from the main viable market centres, poor institutional support networks and a biased policy environment (Makindara et al., 2013). In the low rainfall and high temperature areas of Southern Africa, agricultural production, processing, marketing and consumption systems are dominated by maize at the expense of potential 'orphan crops' such as sorghum. The latter has been side lined and remains labelled as a 'poor farmer's crop' which receives minimal support from value chain stakeholders (Rukuni et al., 2006). This matrix compromises efficiency in executing functions along sorghum value chains by exposing sorghum not only to unhealthy competition among value chain actors, but from other livelihood options as well.

In Zimbabwe, the advent of economic reforms in the early 1990s triggered agricultural diversification based on competitive advantages of productivity gains and emergence of more rewarding markets (Mutenje et al., 2010). A stakeholder re-awakening induced reduction in over dependency on maize was anticipated, especially in arid and semi-arid areas where there was excessive need for irrigation if the crop was to perform well. Notably, this phase culminated in temporary support reduction towards maize with some crops such as sorghum and cotton being embraced by farmers due to guaranteed markets. However, post this era, the government reversed support mechanisms which saw the maize value chain re-dominating (Rukuni et al., 2006). This dampened the commercialisation prospects of sorghum and other small grain crops due to limited extension services, relatively high transaction costs, inadequate and erratic supply, traceability challenges, poor quality and grading. Coupled with the availability of maize from local and regional markets at relatively lower prices, this has continuously pushed sorghum towards extinction from the production, processing, marketing and consumption domains. Studies have shown that there is limited value addition activities with sorghum and this has compromised the crop's potential to generate sustainable margins for actors along multiple value chain nodes (Aduguna, 2007).

Guided by Angelucci and Conforti (2010), Giuliani, Pietrobelli and Rabellotti (2005), as well as Westlake (2014), the study maps the major market routes for sorghum from local to terminal markets. It further identifies the associated challenges and opportunities and estimates the marketing margins for selected value chain actors.

\subsection{Sorghum value chain experiences}

Value chains are important for development of economies (Porter, 1985; Taylor, 2005). Value addition is critical in the success of agricultural commodity value chains. Tchale and Keyser (2010) and the World Bank (2006) report that high income countries add US\$185 of value by processing one tonne of agricultural products as compared to their developing counterparts who add US $\$ 40$. Furthermore, 98\% of agricultural production in developed countries undergoes industrial processing with only $38 \%$ being processed in developing countries. This variance is attributed to low levels of development in agro-value chains in developing countries which underutilise the full potential of the agricultural sector. Interestingly, lessons from the sorghum value chain in the USA show that the stock feed industry has been driven by sorghum (Gibbon, 2003). In Mali, reports show significant impacts of stakeholders' collaboration on margins (Coulibaly et al., 2014). In Tanzania, the scope for sorghum commercialisation was 
S. Afr. J. Agric. Ext.

Vol. 47 No. 1, 2019: 164 - 178

http://dx.doi.org/10.17159/2413-3221/2019/v47n1a497
Musara, Musemwa,

Mushunje, Mutenje \& Pfukwa

(License: CC BY 4.0)

reported by Rohrbach and Kiriwaggulu, (2007), and encouraging results in a clear beer sorghum based value chain were observed by Makindara et al. (2013). In Southern Africa, value chains have been analysed for sorghum seed in Zambia by Hamukwala et al. (2010), key crops including maize and sorghum in Malawi by Chemionics International Inc. (2009) and fish in Malawi by Phiri et al. (2013). In Northern Africa, value chain studies were conducted by Drost, van Wijk and Mandefro (2012) and then later by Dalipagic and Elepu (2014).

Specific sorghum value chain analyses in Zimbabwe still remain limited. However, Rukuni et al. (2006) observed that Zimbabwe has weak institutional arrangements and structures which are rigid and marginalise sorghum. For example, they reported that extension, research and financial services frameworks used in Zimbabwe are ineffective and unresponsive to the demands of small scale farmers in the arid areas where sorghum performs well. This, coupled with infrastructural inadequacies that characterise small scale farming, has reduced value extraction from sorghum value chains at each nodal link.

\section{METHODS}

\subsection{Study area and data collection}

The study was conducted in the Mid Zambezi Valley of Zimbabwe. The area is semi-arid and receives average rainfall ranging from 350 to $550 \mathrm{~mm}$ coupled with high temperatures averaging $30^{\circ} \mathrm{C}$. Agricultural activities are affected by mid-season dry spells which are common in the area. The region is a blend of multicultural communities with different livelihood strategies (Baudron et al., 2012). Five wards namely Chisunga (Angwa), Mahuwe, Gonono, Chikafa and Chitsungo were purposively selected as dominant sorghum production areas. A total of 380 farmers were proportionately ${ }^{7}$ selected. Six agro-dealers who provide seed, fertilisers and chemicals, 15 traders, three wholesalers, 10 retailers, and two processors were also selected with the help of Agritex officers and farmers. Primary data were collected using Focus Group Discussions (FGDs), key informant interviews and a structured questionnaire. Secondary data were also extracted in the form of financial records from the value chain actors. The participatory value chain analysis methodology was used as guided by Lundy et al. (2012) and Lundy et al. (2007) $)^{8}$.

\subsection{Data analysis}

The study uses mapping techniques based on network analysis to trace relationships along value chain nodes. This helped us to examine the existing practices and the missing links which may be tapped into for the benefit of defining scaling up strategies. Studies on value chain mapping have sketched the networks among actors and presented pictorial schematics. Completing the map entails estimating marketing margins for respective chain actors (Mishili et al., 2009). In order to understand the share of benefits and costs that accrue to each actor, it was imperative to apportion these per actor. There are various approaches to making this presentation (Nang'ole, Mithöfer \& Franzel, 2011), and the most effective method is the tabular approach (Trienekens, 2011; UNIDO, 2009). The Analytic Analysis by Product Table (AAPT) ${ }^{9}$

\footnotetext{
${ }^{7}$ This was done to acknowledge the variability in the population of farmers in each ward and generate a more representative sample.

8 For a more detailed explanation of the steps, see the referenced sources.

9 For a detailed explanation see SMEPS and KIT (2009).
} 
S. Afr. J. Agric. Ext.

Vol. 47 No. 1, 2019: 164 - 178

http://dx.doi.org/10.17159/2413-3221/2019/v47n1a497
Musara, Musemwa,

Mushunje, Mutenje \& Pfukwa

(License: CC BY 4.0)

was used for estimating aggregate production costs incurred by selected stakeholders and the associated marketing margins. Procedures prescribed by Hellin and Meijer (2006) were useful in estimating variable $\operatorname{costs}^{10}$. Due to price and traded volume variations for different marketing channels used by actors, we adopted the weighted average selling price ${ }^{11}$.

\section{RESULTS AND DISCUSSION}

\subsection{Sorghum seed supply systems}

Seed is an important ingredient to the success of agricultural enterprises (Ahmed, Sanders \& Nell, 2000). Farmers reported that currently there are low volumes of high yielding seed varieties from research centres which are only complimented by insignificant community based seed production initiatives (Table 1).

Table 1: Major varieties grown by households in the sampled wards

\begin{tabular}{|l|c|c|c|c|c|}
\hline Ward & \multicolumn{5}{|c|}{ Variety and associated respondents (\%) } \\
\hline & Chibuku & Kandevha & Kanzvonzvo & Macia & Silla \\
\hline Angwa (2) & 11 & 15 & 7 & 48 & 19 \\
\hline Chikafa (12) & 5 & 13 & 10 & 24 & 48 \\
\hline Chitsungo (10) & 0 & 14 & 43 & 14 & 29 \\
\hline Gonono (4) & 5 & 8 & 6 & 33 & 48 \\
\hline Mahuwe (15) & 4 & 8 & 3 & 35 & 50 \\
\hline Total sample & $\mathbf{6}$ & $\mathbf{1 0}$ & $\mathbf{8}$ & $\mathbf{3 4}$ & $\mathbf{4 2}$ \\
\hline
\end{tabular}

Source: Field survey 2016.

Notes: Ward number in parenthesis.

The picture in Table 1 is a far cry when compared to maize where about 20 hybrid varieties were used by farmers in the same period. This is because of ready markets for hybrid maize seed by small and large scale farmers. Discussions with farmers and extension officers showed that minimal research and development into sorghum seed production is done by both public and private value chain actors. The government in partnership with the International Crops Research Institute for the Semi-Arid Tropics (ICRISAT) are involved in research, release of new varieties, certification and seed quality control. In the private sorghum seed system, production of improved seed hybrid and open pollinated varieties (OPV) is done through large international seed companies such as PANNAR and SeedCo.

\subsection{Sorghum seed sources and common types of transactions}

Results show that there are limited options through which smallholder farmers in the Mid Zambezi Valley of Zimbabwe acquire improved varieties of sorghum seed. The most widely accessible source is local agro-dealers who buy from large seed companies in bulk and re-sell to farmers. They are however unreliable, and the transaction type is mainly on a cash basis.

10 Since a unit of production has a unit input requirement, calculation of variable costs was straight forward. Transportation costs had a fixed flat charge assigned by commercial transporters and this affected the marginal unit cost which was then determined by volumes traded. In cases where the real costs were not available from secondary data sources, we made use of average costs estimates. Post-harvest handling losses were accounted for. 11 This is more effective as compared to traditional average price used when evaluating economic performance of value chains. 
S. Afr. J. Agric. Ext.

Vol. 47 No. 1, 2019: 164 - 178

http://dx.doi.org/10.17159/2413-3221/2019/v47n1a497
Musara, Musemwa,

Mushunje, Mutenje \& Pfukwa

(License: CC BY 4.0)

Evidence from FGDs revealed that farmers are exposed to exorbitant prices and unreliable supply. Given that demand for sorghum seed by farmers from dealers is minimal, quality of seed is not guaranteed and there are chances of buying expired seed.

Another source of attaining sorghum seed is contractual arrangements between farmers and processing companies such as Delta Beverages and ProFeeds Pvt. Ltd. Lead farmers are mainly used as agents by contractors. Inputs are provided on an agreement that farmers guarantee the right of first refusal to contractors during the marketing season. Contractors sometimes provide extension services so as to improve on quality of produce to meet their processing needs. Barrett et al. (2012) also report similar strategies. The major challenge is that farmers fail to provide the volumes and quality required by contractors. In addition to poor extension and inappropriate management practices, extreme weather patterns have also reduced yields.

Partnerships are critical to the success of value chains (Gibbon, 2003). The government has also partnered Non-Governmental Organisations (NGOs) such as Plan International, Action Aid and French Agricultural Research Centre for International Development (CIRAD) in implementing input subsidy programmes to assist smallholder farmers in acquiring improved seed. Discussions revealed that although farmers are aware of these programmes, they rarely benefit from them since they usually target influential community members. Some farmers have intentionally ignored participating because of missing markets since the organisations do not provide markets for the produce. This is the case with most 'orphan crops' in Africa where uptake of subsidy programmes has been low (Ricker-Gilbert, Jayne \& Chirwa, 2011).

\subsection{Prices and effective demand for sorghum seed}

Approximately $87 \%$ of farmers in sampled wards use recycled or retained seed and rarely buy improved sorghum varieties because they cannot afford to buy seed from agro-dealers and/or vendors. This pattern was also reported by Hamukwala et al., (2010). Access to working capital remains a challenge in African agriculture (Fries \& Akin, 2004; Hosu \& Mushunje, 2013). Discussions show that farmers have no access to credit lines from established financial institutions such as banks. Farmers in Mahuwe report that there are informal lenders in their communities, but the cost of loans are prohibitive and pegged at on average $75 \%$ interest rate. There is need for extension agents to facilitate formation of cooperatives and community based savings clubs. A survey of sorghum seed sources reflects variations in prices of improved sorghum seed with variety. Prices of OPV varieties such as Chibuku and Kandevha are lower than for hybrid varieties such as SC Macia.

Table 2: Average sorghum seed prices observed in the selected wards

\begin{tabular}{|l|c|}
\hline Sorghum variety & Average price (US\$/kg) \\
\hline SC Macia & $1.1-1.32$ \\
\hline SC Sila & 1.2 \\
\hline Chibuku & 0.88 \\
\hline Kandevha & 0.77 \\
\hline Other unspecified local varieties & $0.63-0.70$ \\
\hline
\end{tabular}

Source: Survey data 2016

Table 2 shows that prices of OPVs range from US\$0.63-0.88 per kilogram whilst prices of hybrid seed range from US\$1.1-1.32 per kilogram. 
S. Afr. J. Agric. Ext.

Vol. 47 No. 1, 2019: 164 - 178

http://dx.doi.org/10.17159/2413-3221/2019/v47n1a497
Musara, Musemwa,

Mushunje, Mutenje \& Pfukwa

(License: CC BY 4.0)

\subsection{Other inputs}

An important input in cereal crop production is inorganic fertilizer (Shapiro \& Sanders, 1998). The survey with agro-dealers showed that the most common fertilizer sold is NPK with Urea emerging as an alternative. In practice, however, the major supplier of inorganic fertilizers are NGOs through various development programmes. Due to excessive competition for fertilizer, a limited proportion reaches smallholder farmers through normal markets. If it happens, prices are expensive and prohibitive to many farmers. Farmers reported that they cannot afford prices even when subsidised and use of inorganic fertilizers is limited among farmers. Farmers also do not use standard fertilizer application rates as they spread available fertilizer thinly to cover a large area. This was also reported by Tittonell and Giller (2013).

\subsection{Constraints on performance of the input sector}

Government and NGOs input subsidy programmes have the tendency to reduce business available to agro-dealers and frequency of transactions in open markets (Ricker-Gilbert et al., 2011). Agro-dealers reported that transaction costs are high due to several middlemen between them and manufacturers. Direct access to manufacturers would reduce the selling price. Discussions showed that there is generalised limited growth in markets for sorghum seed and fertilizers. There is limited access to input markets by smallholder sorghum farmers. The main markets are found in district centres and provincial capitals which are far from farmers and hence significant transport costs are incurred. During discussions, farmers and agro-dealers reported that markets for their products are approximately $100 \mathrm{~km}$ away. There is also poor reinforcement of sorghum seed quality control since the crop is treated as peripheral in mainstream agricultural development. Vendors sometimes sell counterfeit seeds thereby eroding farmers' trust. Supply of inputs is not always adequate, continuous and reliable. There are periods when agro-dealers fail to obtain inputs on time from wholesalers, thus affecting availability for farmers. Evidence shows that unavailability of seed and finance were major constraints to uptake of sorghum as a livelihood enhancing strategy. Due to the dynamic nature of agricultural activities in this arid area, some agro-dealers have limited information on what farmers require and at what specific time. Similarly, farmers also have limited knowledge on markets, marketing dynamics, different products available and prices. A supplier-consumer critical success factor (CSF) analysis conducted shows this mismatch and expectations as in Figure 2.

Farmers are mainly concerned with prices, innovations and availability of credit facilities. Yet, suppliers are concerned with conformance and financing. This conflict distorts functioning of sorghum input markets. 
S. Afr. J. Agric. Ext.

Vol. 47 No. 1, 2019: 164 - 178

http://dx.doi.org/10.17159/2413-3221/2019/v47n1a497
Musara, Musemwa,

Mushunje, Mutenje \& Pfukwa

(License: CC BY 4.0)

\section{Sorghum inputs suppliers and farmers' perception of CSFs}

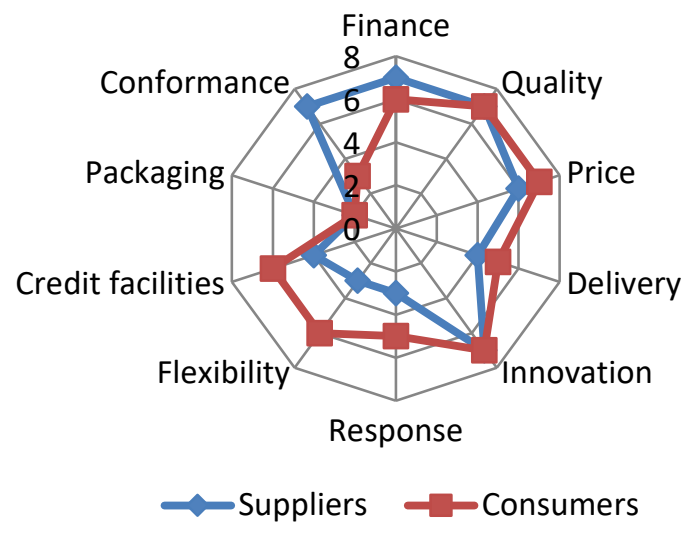

Figure 2: CSF analysis for sorghum markets

Source: Survey data 2016

\subsection{Production of sorghum}

Sorghum is one of the most important cereal crops in the Mid Zambezi Valley with the potential to be included in the main staple basket. Both subsistence and commercial cultivation is done in almost all parts of the zone at different levels using varied resources. Productivity averages $0.9 \mathrm{MT} / \mathrm{ha}$, which is higher than the national average of $0.5 \mathrm{MT} / \mathrm{ha}$ (Mukarumbwa \& Mushunje, 2010). This can be improved if input markets are developed and use of improved seed varieties and inorganic fertilizer is enhanced. An analysis of average land allocated and productivity levels across the sampled wards is shown in Figure 3.

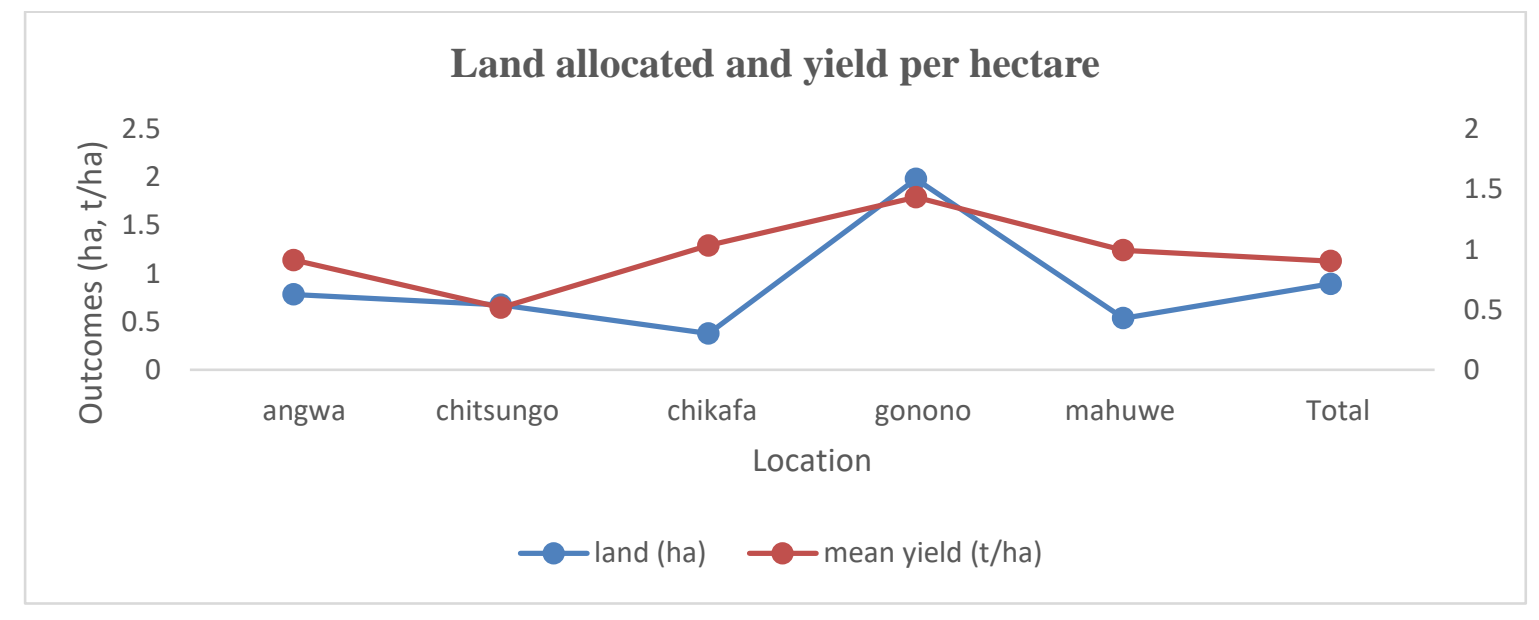

Figure 3: Sorghum land allocation and average productivity by ward

Source: Survey data 2016

Gonono is the prime sorghum producing zone in the area and dominates in both average lands allocated to sorghum (2ha) and productivity (1.4MT/ha). Farmers accept that the crop is a core 
S. Afr. J. Agric. Ext.

Vol. 47 No. 1, 2019: 164 - 178

http://dx.doi.org/10.17159/2413-3221/2019/v47n1a497
Musara, Musemwa,

Mushunje, Mutenje \& Pfukwa

(License: CC BY 4.0)

source of livelihood and have configured production and networking practices to take advantage of its potential.

\subsection{Production related constraints}

Most smallholder sorghum production is done for subsistence because of the view that sorghum is not economically rewarding due to missing markets, market failure and limited support (Laico, Mourik \& Brocke, 2011). In response, the government and NGOs have initiated projects to promote conservation agriculture with sorghum. This was anticipated to incentivise farmers by providing inputs and linkages to potentially viable markets. However, uptake of these initiatives remains low. In these drier parts where sorghum can be allocated reasonable land, extreme climatic conditions, especially mid-season dry spells, affect its performance. Farmers reported that in most cases, they leave the crop in the field when rainfall is inadequate. They anticipate that sorghum remains dormant and when rains come it will sprout and grow. However, significant yield losses were reported.

\subsection{Processing and marketing}

There are limited channels through which small scale farmers sell their sorghum produce. Farmers mainly sell sorghum to small scale traders who in turn sell to medium scale traders who eventually sell to large scale traders in Mvurwi, Bindura and Harare. Small scale local traders sometimes store sorghum and sell it back to farmers during lean periods at higher prices. Large scale traders sell to processors of mealie meal, stock feed and beer. Some farmers sell their sorghum directly to consumers in villages or roadside markets. Contracted farmers sell to contractors with reported cases of side marketing due to lower prices compared to the open markets. Three marketing options were isolated as shown in Figure 4.

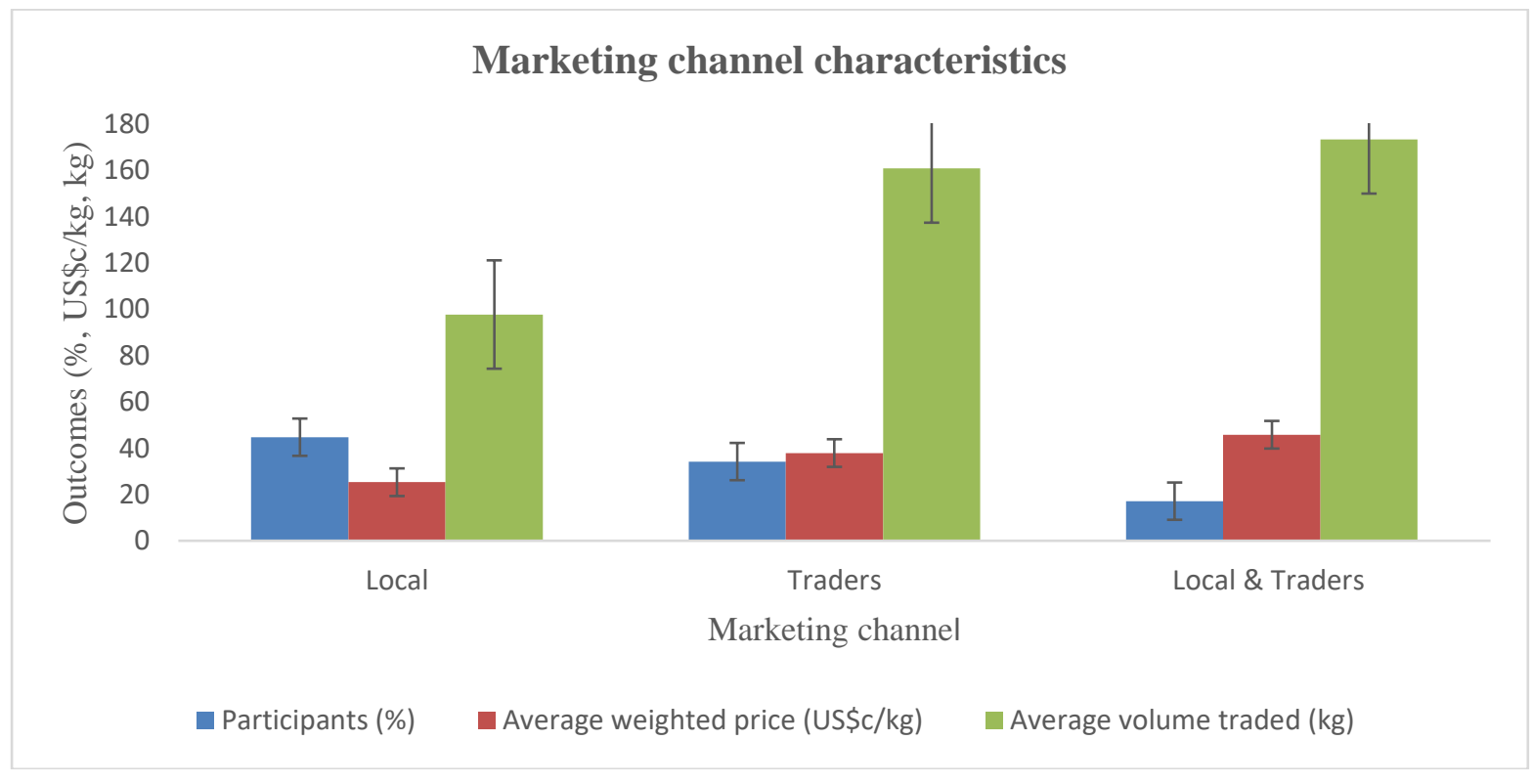

Figure 4: Sorghum grain marketing channels and associated attributes

Source: Survey data 2016 
S. Afr. J. Agric. Ext.

Vol. 47 No. 1, 2019: 164 - 178

http://dx.doi.org/10.17159/2413-3221/2019/v47n1a497
Musara, Musemwa,

Mushunje, Mutenje \& Pfukwa

(License: CC BY 4.0)

Figure 5 shows comparative prices per kilogramme for sorghum seed and sorghum grain. Farmers who produce seed enjoy higher market prices as compared to those who produce grain. However, in most cases, farmers do not produce sorghum seed due to the numerous demands associated with the production.

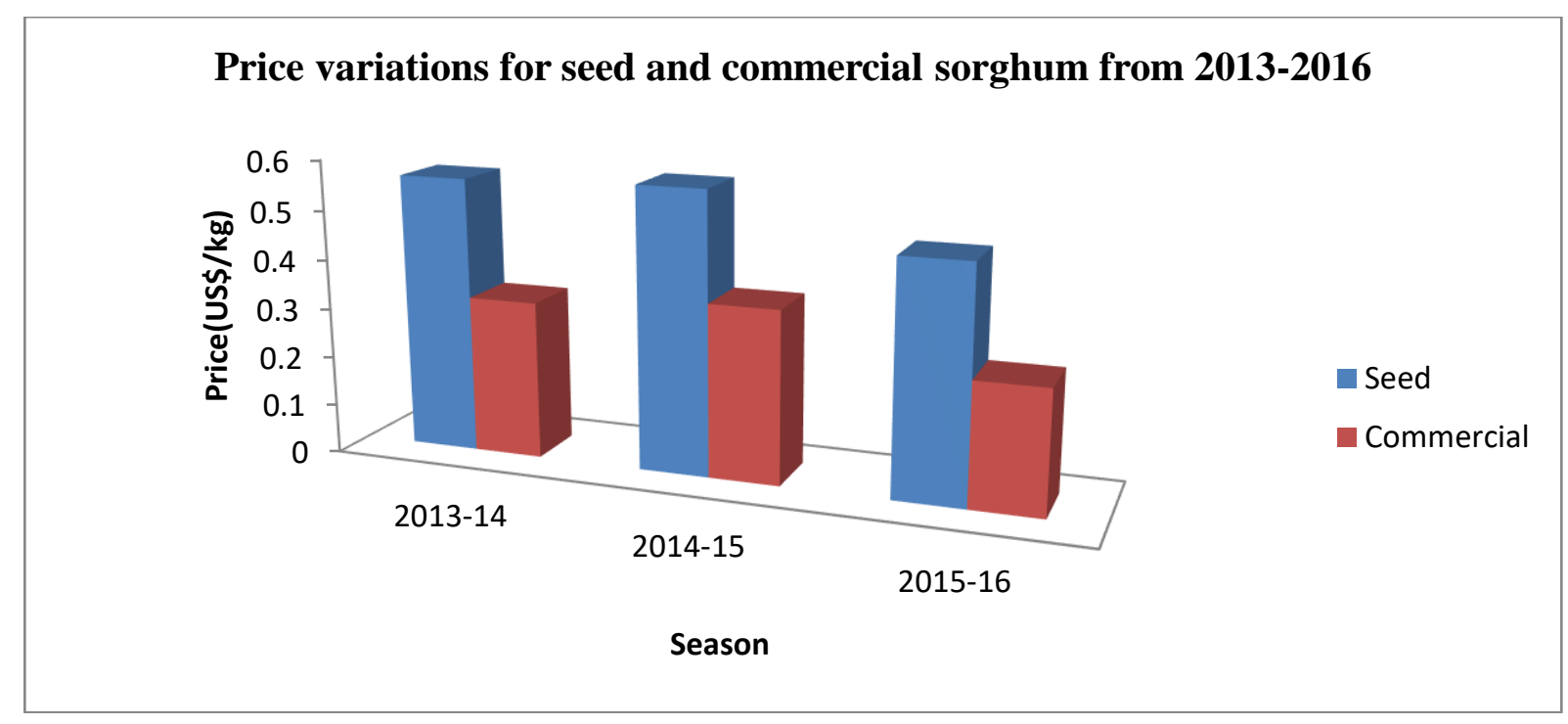

Figure 5: Sorghum seed and grain prices

Source: Survey data 2016

\subsection{Sorghum grain processing and marketing constraints}

FGDs showed that the major constraint to sorghum grain marketing is low and variable producer price which fluctuates between and within markets depending on progression of the marketing season. Prices are lowest immediately after harvesting and can peak during lean season periods. These prices do not support sorghum production as a reliable source of income. Farmers and traders alike also reported challenges in sorghum grain storage which also affects marketing decisions. Farmers are unable to keep grain for longer periods until price in markets has improved because they do not have proper storage facilities and/or cannot afford to buy pesticides to fumigate their produce. Physical loss is mainly as a result of pest and rodents while quality deterioration is caused by humidity.

There are several players involved in sorghum processing including millers, beer brewing companies and stock feed manufacturing companies. Small scale millers own grinding mills and process sorghum grain into mealie meal as and when required. In urban centres there are relatively more organised and large scale actors involved in processing and packaging of mealie meal and stock feed for onward sale to wholesalers and retailers. However, due to unreliable and low supply of sorghum grain, most stock feed processors shun using the grain as a raw material regardless of its high crude protein content. Figure 6 shows a complete sorghum value chain map. 
S. Afr. J. Agric. Ext.

Vol. 47 No. 1, 2019: 164 - 178

http://dx.doi.org/10.17159/2413-3221/2019/v47n1a497
Musara, Musemwa,

Mushunje, Mutenje \& Pfukwa

(License: CC BY 4.0)

\subsection{The role of extension in strengthening the sorghum value chain}

Rukuni et al. (2006) reported that extension agents play an integral role in linking farmers with various actors along agricultural commodity value chains. Rohrbach \& Kiriwaggulu (2007) postulate that in small scale farming areas of Sub-Saharan Africa, different forms of extension driven farmer support programmes and cooperation arrangements have existed for a long time as an effort to commercialise sorghum. The practices have been premised on the need for extension agents to coordinate small scale sorghum production, processing and marketing through linkages with agribusiness companies. Given the above observations, an integrated and extension oriented mentality by sorghum value chain stakeholders needs to be urgently adopted. This can be catalysed through changes in knowledge generation and dissemination structures, attitudes and skills development. In future, this should drive networking and grease the sorghum value chain wheels for easy access to factor and product markets by stakeholders (Hamukwala et al., 2010). Ultimately, this will inspire a new revolution for coordination in various sorghum value chain nodes whereby actors can then fully exploit their competitive advantages through execution of activities and bargaining for higher shares. Guided by this vision, there is a need for significant investment in research and extension services delivery systems along the sorghum value chain. This should help the small scale farmers to become an integral participant in the sorghum value chain. 
Musara, Musemwa,

Mushunje, Mutenje \& Pfukwa

(License: CC BY 4.0)

\section{Financing, Research and Quality Control}

NARIs, ICRISAT, Department of Research and Specialist Services, NGOs, Consumer Organisations

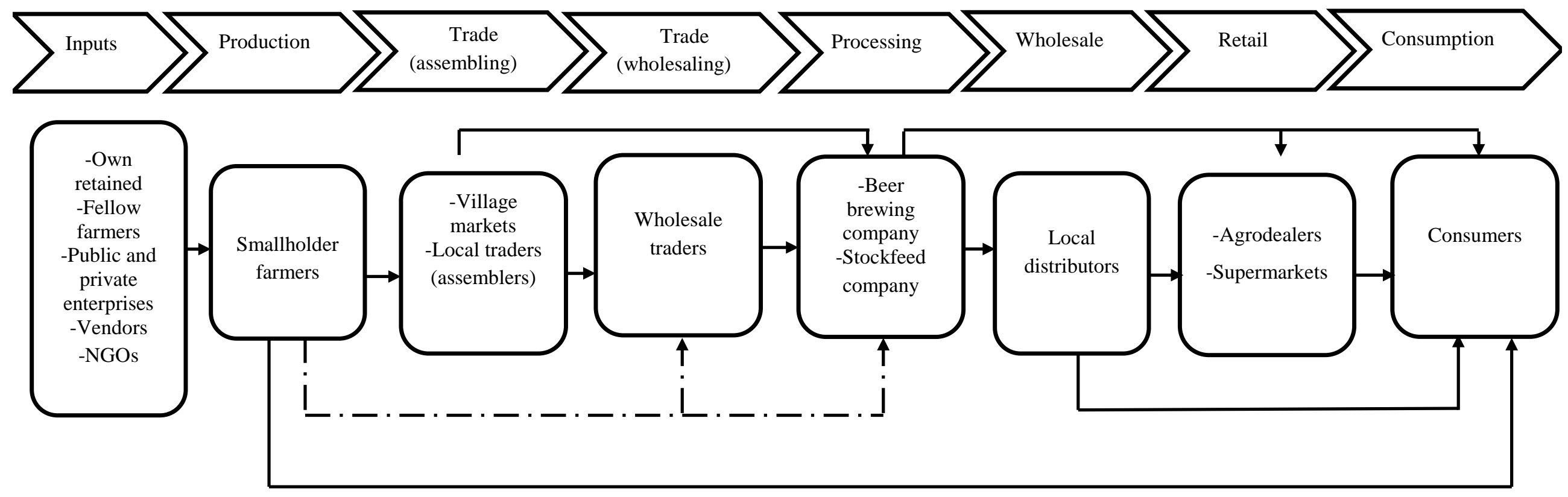

Key:

-...- Existing relationships

Figure 6: Value chain map for sorghum in Mid Zambezi Valley, Zimbabwe

Source: Survey data 
S. Afr. J. Agric. Ext.

Vol. 47 No. 1, 2019: 164 - 178

http://dx.doi.org/10.17159/2413-3221/2019/v47n1a497
Musara, Musemwa,

Mushunje, Mutenje \& Pfukwa

(License: CC BY 4.0)

\section{CONCLUSION}

Input supply systems for sorghum are poorly developed with evidence of limited active coordination in research. Farmers have limited options of improved hybrid and open pollinated sorghum seed varieties available in markets. Production constraints include limited use of fertilizer, extensive use of recycled seed, lack of agricultural equipment, and natural hazards. Farmers have limited options for marketing sorghum produce with a few active actors in the sorghum output markets who dictate prices. The farm-gate price for sorghum is low and discourages uptake of sorghum as an income source. Thus, the combination of these factors results in farmers being exposed to a low price for sorghum grain soon after harvest and during lean periods they buy the same sorghum from small and medium scale traders at about twice their selling price.

\section{IMPLICATIONS FOR POLICY}

The most important strategy is to create effective demand for sorghum inputs by helping farmers realise the benefits of using improved sorghum seed varieties and fertilizer. Promotion of improved sorghum seed varieties in target communities by extension agents is critical towards attaining the potential yield of about 3.5MT/ha. Extension agents could conduct onfarm demonstrations and field days which can create the much needed awareness. Government could explore input subsidies to encourage adoption of improved sorghum seed varieties. It is also important to promote contract farming through organising farmers into cooperatives or associations. This will also assist with group marketing of produce. In addition, agro-dealers should be supported with funding mechanisms to grow their business and expand into new markets. If a value chain is linked and efficient from inputs, production, marketing and processing, then it is not difficult to increase production of targeted crops through the use of recommended inputs because there is guaranteed value for all actors.

\section{ACKNOWLEDGEMENT}

This work was conducted within the framework of the Research Platform "Production and Conservation in Partnership" (www.rp-pcp.org). This document has been produced with the financial assistance of the European Union. The contents of this document are the sole responsibility of the authors and can under no circumstances be regarded as reflecting the position of the European Union.

\section{REFERENCES}

ADUGUNA, A., 2007. The role of introduced sorghum and millets in Ethiopian agriculture. SAT eJournal, 3(1):1-4.

AHMED, M.M., SANDERS, J.H. \& NELL, W.T., 2000. New sorghum and millet cultivar introduction in Sub-Saharan Africa: Impacts and research agenda. Agric. Sys., 64(1):5565.

ANGELUCCI, F. \& CONFORTI, P., 2010. Risk management and finance along value chains of small island developing states. Evidence from the Caribbean and the Pacific. Food Policy, 35(6):565-575. 
S. Afr. J. Agric. Ext.

Vol. 47 No. 1, 2019: 164 - 178

http://dx.doi.org/10.17159/2413-3221/2019/v47n1a497
Musara, Musemwa,

Mushunje, Mutenje \& Pfukwa

(License: CC BY 4.0)

BARRETT, C.B., BACHKE, M.E., BELLEMARE, M.F., MICHELSON, H.C., NARAYANAN, S. \& WALKER, T.F., 2012. Smallholder participation in contract farming: Comparative evidence from five countries. World Dev., 40(4):715-730.

BAUDRON, F., TITTONELL, P., CORBEELS, M., LETOURMY, P. \& GILLER, K.E., 2012. Comparative performance of conservation agriculture and current smallholder farming practices in semi-arid Zimbabwe. Field Crops Res., 132:117-128.

CHEMIONICS INTERNATIONAL INC. 2009. Staple foods value chain analysis. Available from: http://www.fao.org/sustainable-food-value-chains/library/details/en/c/236730/

COULIBALY, J.Y., SANDERS, J.H., PRECKEL, P.V. \& BAKER, T.G., 2014. Will cotton make a comeback in Mali? Agric. Econ., 46(1):53-67.

DALIPAGIC, I. \& ELEPU, G., 2014. Agricultural value chain analysis in Northern Uganda: Maize, rice, groundnut, sunflower and sesame. ACF-International.

DROST, S., VAN WIJK, J. \& MANDEFRO, F., 2012. Key conditions for successful value chain partnerships : A multiple case study in Ethiopia. The Partnerships Resource Centre Working Paper No. 03.

FRIES, R. \& AKIN, B., 2004. Value chains and their significance for addressing the rural finance challenge. Accelerated Microenterprise Advancement Project, MicroREPORT No. 73, Washington DC.

GIBBON, P., 2003. Commodities, donors, value-chain analysis and upgrading. Available from: http://www.rmportal.net/framelib/commodities-donors-value-chain.pdf

GIULIANI, E., PIETROBELLI, C. \& RABELLOTTI, R., 2005. Upgrading in global value chains: Lessons from Latin American clusters. World Dev., 33(4):549-573.

GULATI, A., MINOT, N., DELGADO, C. \& BORA, S., 2007. Growth in high-value agriculture in Asia and the emergence of vertical links with farmers. Food Policy, 91-108.

HAMUKWALA, P., TEMBO, G., LARSON, D. \& ERBAUGH, M., 2010. Sorghum and pearl millet improved seed value chains in Zambia: Challenges and opportunities for smallholder farmers. INTSORMIL Scientific Publications., 3.

HELLIN, J. \& MEIJER, M., 2006. Guidelines for value chain analysis. Food and Agricultural Organization (FAO).

HOSU, S. \& MUSHUNJE, A., 2013. Optimizing resource use and economics of crop-livestock integration among small farmers in semiarid regions of South Africa. Agroecol. Sust. Food, 37(9):985-1000.

LAICO, H., MOURIK, T.V. \& BROCKE, K.V., 2011. Bringing technological innovations for sorghum and millet to farmers in Mali. Harnessing opportunities for productivity enhancement of sorghum and millets in Sub-Saharan Africa and South Asia. 30 Ans De Partenariat Mali-Fondation Syngenta, Quels Impacts Pour L'agriculture Malienne? Hotel Laico, Bamako, October 5-7, pp: 5-7. 
S. Afr. J. Agric. Ext.

Vol. 47 No. 1, 2019: 164 - 178

http://dx.doi.org/10.17159/2413-3221/2019/v47n1a497
Musara, Musemwa,

Mushunje, Mutenje \& Pfukwa

(License: CC BY 4.0)

LUNDIY M., BECX, G., ZAMIEROWSKI, N. \& RODRIGUEZ, F., 2012. LINK methodology: A participatory guide to business models that link smallholders to markets. Columbia: Centro Internacional de Agricultura Tropical (CIAT)

LUNDY, M., GOTTRET, M.V., OSTERTAG GÁLVEZ, C.F., BEST, R. \& FERRIS, S., 2007. Participatory market chain analysis for smallholder producers. Columbia: Centro Internacional de Agricultura Tropical (CIAT)

MAKINDARA, R., HELLA, J.P., ERBAUGH, J.M. \& LARSON, D.W., 2013. Consumer preferences and market potential for sorghum based clear beer in Tanzania. J. Brew. Distilling., 4(1):1-10.

MISHILI, F.J., FULTON, J., SHEHU, M., KUSHWAHA, S., MARFO, K., JAMAL, M., CHERGNA, A. \& LOWENBERG-DEBOER, J., 2009. Consumer preferences for quality characteristics along the cowpea value chain in Nigeria, Ghana and Mali. Agribusiness, 25(1):16-35.

MUKARUMBWA, P. \& MUSHUNJE, A., 2010. Potential of sorghum and finger millet to enhance household food security in Zimbabwe's semi-arid regions: Joint 3rd African Association of Agricultural Economists (AAAE) and 48th Agricultural Economists Association of South Africa (AEASA) Conference, Cape Town, South Africa, September 19-23.

MUTENJE, M.J., ORTMANN, G.F., FERRER, S.R D. \& DARROCH, M.A.G., 2010. Rural livelihood diversity to manage economic shocks: Evidence from South-East Zimbabwe. Agrekon, 49(3):338-357.

NANG'OLE, E.M., MITHÖFER, D. \& FRANZEL, S., 2011. Review of guidelines and manuals for value chain analysis for agricultural and forest products. Kenya: World Agroforestry Centre

PHIRI, L.Y., DZANJA, J., KAKOTA, T. \& HARA, M., 2013. Value chain analysis of lake Malawi fish: A case study of Oreochromis spp (Chambo). International Journal of Business and Social Science, 4(2):170-181.

PORTER, M., 1985. The competitive advantage: Creating and sustaining superior performance. The Free Press.

PYE-SMITH, C., 2013. Making the connection: Value chains for transforming smallholder agriculture. CTA.

RICKER-GILBERT, J., JAYNE, T.S. \& CHIRWA, E., 2011. Subsidies and crowding out: A double-hurdle model of fertilizer demand in Malawi. Am. J. Agric. Econ., 93(1):26-42.

ROHRBACH, D.D. \& KIRIWAGGULU, J.A.B., 2007. Commercialization prospects for sorghum and pearl millet in Tanzania. J. SAT Agric. Res, 3(1):1-25.

RUKUNI, M., TAWONEZVI, P., EICHER, C., MUNYUKI-HUNGWE, M. \& MATONDI, P., 2006. Zimbabwe's agricultural revolution revisited. Harare: University of Zimbabwe Publications. 
S. Afr. J. Agric. Ext.

Vol. 47 No. 1, 2019: 164 - 178

http://dx.doi.org/10.17159/2413-3221/2019/v47n1a497
Musara, Musemwa,

Mushunje, Mutenje \& Pfukwa

(License: CC BY 4.0)

SARRIS, A. \& MORRISON, J.E., 2010. Food security in Africa: Market and trade policy for staple foods in Eastern and Southern Africa. Edward Elgar Publishing.

SHAPIRO, B.I. \& SANDERS, J.H., 1998. Fertilizer use in semiarid West Africa: Profitability and supporting policy. Agric. Sys., 56(4):467-482.

TAYLOR, D.H., 2005. Value chain analysis: An approach to supply chain improvement in agri-food chains. Int. J. Phys. Distrib. Logist. Manag., 35(10):744-761.

TCHALE, H. \& KEYSER, J., 2010. Quantitative Value chain analysis: An application to Malawi. Policy Research Working Paper No. 5242.

TITTONELL, P. \& GILLER, K.E., 2013. When yield gaps are poverty traps: The paradigm of ecological intensification in African smallholder agriculture. Field Crops Res., 143, 7690.

TRIENEKENS, J.H., 2011. Agricultural value chains in developing countries: A framework for analysis. Int. Food Agribus. Man., 14(2):51-82.

UNIDO, 2009. Agro-value chain analysis and development: The UNIDO approach. Vienna: United Nations Industrial Development Organisation.

WESTLAKE, M.J., 2014. Opportunities for sustainable, green and inclusive agricultural value chains in ACP countries. Technical Centre for Agricultural and Rural Cooperation.

WORLD BANK, 2006. Mozambique agricultural development strategy - stimulating smallholder agricultural growth. Report No. 32416-MZ. 